\title{
The United Kingdom's response to the 2014-2018 Islamic State Terrorist Group attacks
}

\section{Respon Inggris terhadap serangan Kelompok Teroris Islamic State tahun 2014-2018}

\author{
Dewi Nawar Sri Juita \\ Department of International Relations, Faculty of Social and Political Sciences, \\ Universitas Airlangga \\ Address: Jalan Dharmawangsa Dalam, Airlangga, Surabaya, East Java, Indonesia 60286 \\ E-mail: medewijuita@gmail.com
}

Article History: Received 8 April 2020; Accepted 11 February 2021; Published Online 8 March 2021

\begin{abstract}
Advancements in technology, information, and communication have transformed warfare from a conventional method to psychological warfare (psywar). In the past, warfare was heavily associated with various weapons, such as rifles, bombs, or even nuclear power, to attack an area for specific purposes. In the modern era, warfare is more concerned about technology and information superiority to threaten the enemy faster and more robust. Modern warfare targets the psychology of society in order to win the war. Islamic State (IS) has attracted the world's attention for its successful strategy in using Twitter in waging war on a country, in this case, the United Kingdom. The purpose of this research is to describe the United Kingdom government's response in fighting Islamic State attacks on Twitter. This research uses descriptive methods by collecting data from books, the internet, journals, and scientific articles. This study indicates that the United Kingdom responds to Islamic State attacks through two patterns, hard and soft power. The hard power method is carried out through intelligence, police, and economic power to collaborate with international organizations such as the United Nations. The soft power pattern was implemented by creating official state Twitter accounts such as @ UKAgainstDaesh,@coalition, @TerrorismPolice, and collaboration with the Global Internet Forum CounterTerrorism (GIFCT). This strategy plays an essential role in stopping the spread of online terrorism-related content online by blocking related photos, videos, and texts of terrorism.
\end{abstract}

Keywords: Islamic State; Twitter; United Kingdom; globalization

\begin{abstract}
Abstrak
Kemajuan teknologi, informasi dan komunikasi secara tidak langsung telah mengubah cara perang dari konvensional ke psywar (psychological warfare atau perang urat syaraf). Di masa lalu, peperangan identik dengan penggunaan senjata berat seperti senapan, bom, pistol atau bahkan kekuatan nuklir untuk menyerang suatu wilayah demi kepentingan tertentu. Akan tetapi, di era modern perang lebih mengarah pada superioritas teknologi dan informasi karena dianggap lebih cepat, lebih kuat serta lebih mengancam dan menargetkan psikologis masyarakat demi memenangkan peperangan tersebut. Islamic State (IS) telah berhasil menarik perhatian dunia karena berhasil memanfaatkan Twitter untuk mengobarkan perang terhadap negara, dalam hal ini adalah Inggris. Tujuan dari penelitian ini untuk mendeskripsikan bagaimana bentuk respon yang dilakukan oleh pemerintah Inggris dalam melawan serangan-serangan Islamic State di Twitter. Jenis penelitian ini berupa studi kepustakaan dengan menggunakan metode deskriptif, mengumpulkan data dari buku, internet, jurnal dan artikel ilmiah. Hasil dari penelitian ini menunjukkan bahwa Inggris merespon serangan Islamic State melalui dua pola yaitu kekuatan keras dan lunak. Pola kekuatan keras dilakukan melalui kerjasama intelijen, polisi, kekuatan ekonomi hingga kerjasama dengan organisasi internasional seperti Perserikatan Bangsa Bangsa. Pola kekuatan lunak dilakukan dengan menciptakan akun Twitter resminegaraseperti@UKAgainsDaesh, @ coalition,@TerrorismPolice dan kerjasama dengan the Global Internet Forum to Counter Terrorism (GIFCT). Hal ini berperan menghentikan penyebaran konten teroris secara online dengan memblokir pesan-pesan teror berupa foto, video, dan teks.
\end{abstract}

Kata Kunci: Islamic State; Twitter, United Kingdom; globalisasi

\section{Introduction}

The development of communication technology has shifted the definition of world security and defense. Harrison (2018) stated that technology could change the way individuals exposes to radicalization and planning attacks. The online platform offers more opportunities to accelerate the 
radicalization process in its operational planning. Islamic State (hereafter called IS) is an essential issue in current international affairs because its existence is threatening world peace. RAND (2019) states that the IS, also known as ISIS (Islamic State of Iraq and Syria), or as ISIL (the Islamic State of Iraq and the Levant), was based on a violent ideology (different from previous terrorists), addressing themselves as the caliph, the one who will establish the Caliphate. They justify any action to achieve their goal by claiming authority over all Muslims. This research aims to analyze how the United Kingdom government responds to IS attacks on Twitter.

Islamic State uses an online platform to spread propaganda by calling on all Muslim communities to carry out jihad (holy war) to achieve its political interests. They intend to kill infidel (people who do not believe in Allah) and people who obstruct their movement by publishing videos, texts, and photos (Boyle \& Akbar 2017). This propaganda is disseminated through various technological and communication instruments. Twitter has become one of the platforms used by IS to threaten the state, spread radical ideologies, and appeal to its members in the group's agenda. Thus, Twitter has become an essential communication tool IS to wage war with countries they perceive as threats

The United Kingdom is a state that is experiencing destabilization where 500 of its Muslim group have traveled to Syria to join the IS. Three hundred other people have returned to the United Kingdom and carried out open attacks on western countries (Stuart 2014). In the past, warfare was synonymous with heavy weapons, such as rifles, bombs, pistols, or even nuclear to attack an area, while, in the modern era, warfare involves the superiority of technology to intrude human psychology instead of attacking areas. The United Kingdom has performed a systematic strategy in fighting terrorists. It collaborates with intelligence from significant countries, and the United Kingdom also seeks cooperation with international organizations such as the United Nations. In responding to IS attacks, the United Kingdom formed a Twitter account in 2015 under the name @UKAgainstDaesh. Perraudin (2015) said that the first tweet from the @UKAgainstDaesh account was a 30-second video published on 28 August 2015, at 5:28 pm. The video has been watched by $10.4 \mathrm{k}$ Twitter users and received 315 comments and 111 likes from Twitter users.

In the short video, the United Kingdom delivered several messages. First, the United Kingdom responded to IS by placing government positions on events conducted by IS. Second, the United Kingdom seeks to block their society from joining the extreme IS group. The final message is that the United Kingdom will block radical sites that are considered disturbing and threatening its security. This study examines the response of the United Kingdom government in countering Islamic State attacks through social media.

\section{Research Method}

This research is a literature study, in which the researcher collected data by reviewing written sources such as books, journals, the internet, and other relevant scientific articles (review or research articles) by using a descriptive method. According to Atmowardoyo (2018), a descriptive method is a research design apt to describe the problem and a research method to describe existing phenomena as accurately as possible. The phenomena observed in descriptive research are available; the researcher needs to collect available data through research instruments such as text, images, and videos. The purpose of descriptive research is to systematically and accurately describe the facts, behavior, and relationships between the studied phenomena. Therefore, this research only focuses on looking at new forms of war via Twitter. This study's data analysis technique adopts from that suggested by Erianto (2011), the qualitative content analysis method. Qualitative methods are used to analyze the content's characteristics and draw inference from a certain communication content, such as speech texts, pamphlets, advertisements, or videos. This type of analysis systematically identifies the visible or invisible content of communication to be carried out objectively, validly, reliably, and can be replicated for further research.

This study's time limit is 2014-2018; the year 2014 was chosen as the beginning era when IS was first seen as a threat by the international state because of its daring acts of terror by circulating radical videos and calling for jihad for the world community. In 2015, the United Kingdom blatantly 
established a Twitter account to countermeasure psychological attacks by IS. In 2018, the United Kingdom's fight against IS started to be expanded by carrying out many collaborations with various fields to protect United Kingdom society.

\section{Result and Discussion}

\section{The form of Islamic State attack}

After the Cold War, the definition of security was undergoing redefinition from merely involving military and weapons as the main power to encompass technological advances in the new war. In the modern era, changes have been made within the discourse of politics, war, and defense. Dickson (2004) stated that war in the modern era emphasizes the power of information, language, symbols, traditions, and techniques to build truth and redefine warfare. Acceleration in communication science, technology, democratization, independent relations between countries, and globalization have been the primary implementers of this phenomenon. Technology has started gaining prominence as a primary strategy for its influence, which could lead to conflict. Militaries properly utilize modern technological systems to enhance command, control, and communications functions at sea or land, between headquarters and remote installations. Therefore, military communication has an important influence on the whole war and conflict sphere (Back \& Thompson 2018).

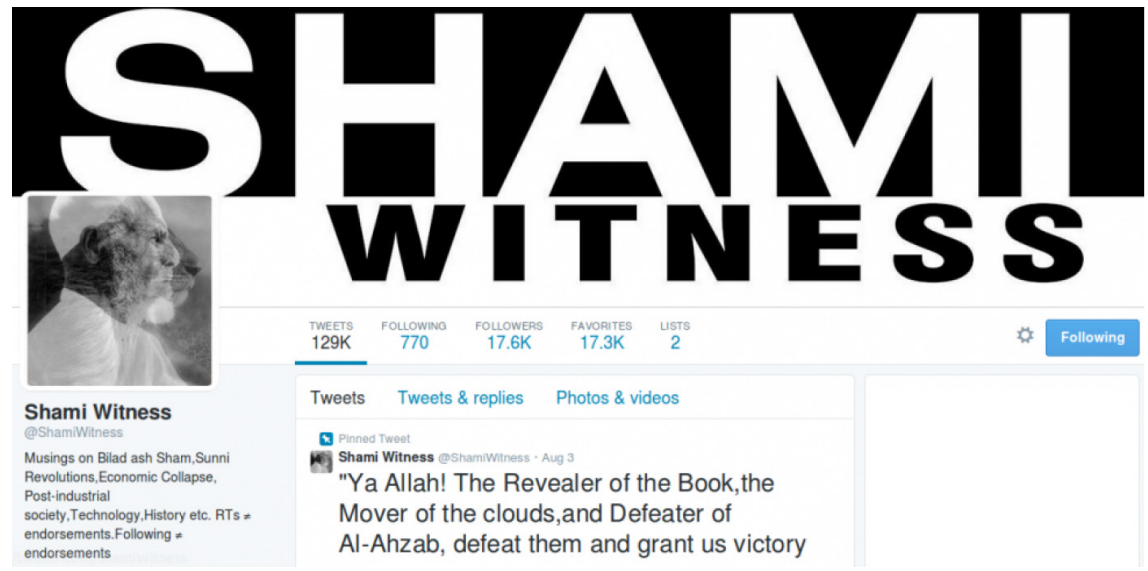

Figure 1.

Twitter account of @ShamiWitness

Source: Channel 4 News (2014)

The development of technology impacts how technology is being utilized, which previously was only used by military forces (McLean 1993). In the present, it can also be used by groups or individuals with a radical ideology such as the IS terrorist group. The era marks the birth of a new war model in the modern era (using the power of technology and the internet to attack countries or individuals who consider a threat). Metz (2007) stated that war relied on military power and arms as the main forces to win wars in the past; however, in modern times, the internet has more influence than real power because it involves networks, organizations, politics, and ideology at once. The focus of the internet warfare attack is even more comprehensive. In addition, Metz (2007) stated that the essence of war would never change, but its nature will change because it involves human psychology. The nature and character of war will be more widespread where animal and human forces will be replaced by more sophisticated mechanisms, such as communication, writing, and email.

\section{Islamic State propaganda through Twitter}

Islamic State or known as the Islamic State of Iraq and Syria (ISIS), and the Islamic State of Iraq and the Levant (ISIL) are known as terrorist movements with radical ideologies that justify various ways to achieve their goals. Muhammad (2015) stated that IS emerged due to three phenomena: first, because of the United States' illegal 2003 invasion of Iraq, second, because of the Syrian conflict outbreak and, third, because of the Shia puppet regime that replaced Saddam Hussein's leadership as the will of the United States. The United States systematically discriminated against the Sunni 
people, giving birth to the IS group. Alexander \& Alexander (2015) stated that, initially, Abu Muzhab Al-Zarqawi was a veteran of the Taliban war from Afghanistan in the 1980s who was once affiliated with Al-Qaeda (a terrorist organization formed by Osama bin Laden). In 2001, Zarqawi decided to move to Iraq after the fall of the Taliban in Afghanistan. In 2004, he performed bay'ah to Osama Bin Laden and formed an Al-Qaeda in Iraq (AQI) group.

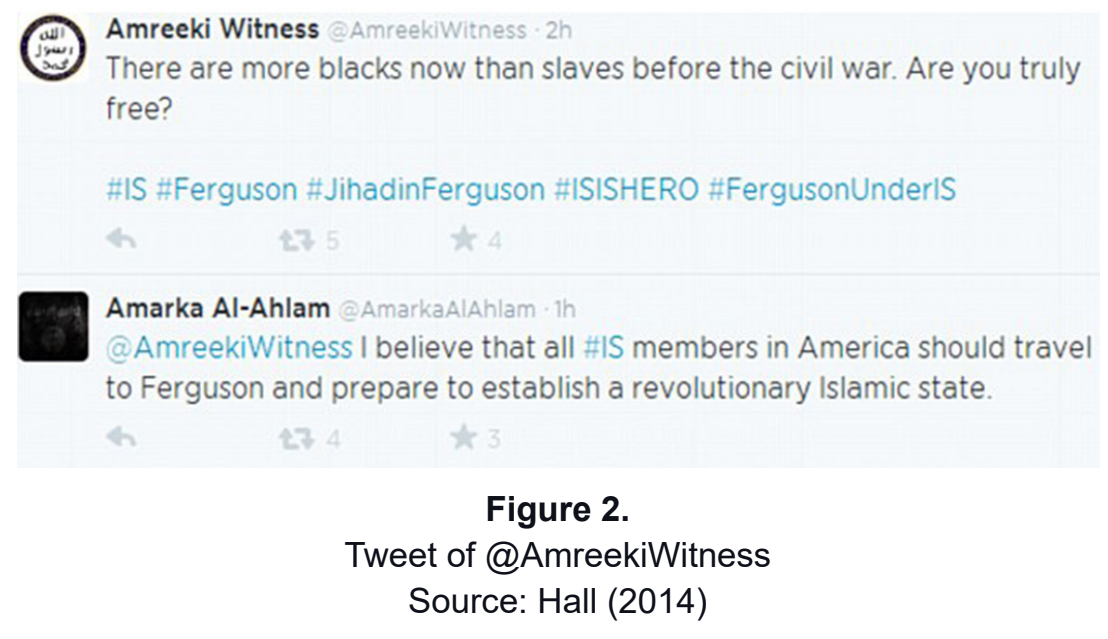

In June 2006, Zarqawi died in the United States airstrikes around Baqouba. At that time, the ISIS leadership was in Abu Ayyub al-Masri's hands with Abu Umar al-Baghdadi. Under their leadership, the name AQI changed to Islamic State in Iraq (ISI), and in 2010, both were killed in American attacks. After a while, their leadership was taken over by Abu Bakr al-Baghdadi and aspired to expand the ISI to Syria. In April 2013, al-Baghdadi decided to change the name of ISI to the Islamic State in Iraq and al-Sham or Levant (ISIL). On 29 June 2014, al-Baghdadi became increasingly active and formed a declaration to establish a new state called the Islamic State (IS) based on the caliphate (Tomé 2015).

To achieve the IS goals, Abu Bakr al-Baghdadi changed his war strategy from field action to virtual action. Islamic State required only a little time to adapt to this new strategy, as they had the expertise to place competent people in their fields. Their actions were very intensive and systematic compared to terrorists in the past. The virtual attacks connected the physical and the cyber dimensions in which cyberspace attacks can also pose equally dangerous threats in the real world.

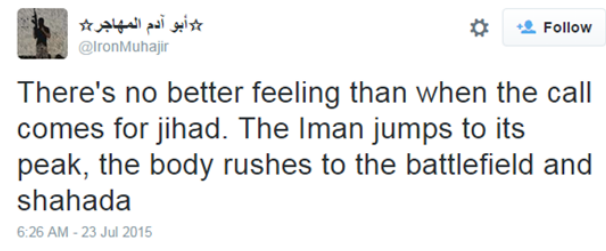

Figure 3.

Tweet of @IronMuhajir

Source: Counter Extremism Project (2015b)

Greenberg (2015) said that, starting on 11 January 2015, IS used Twitter to spread its ideology by sharing a short video of al-Baghdadi's invitation to Muslims to fight by taking up arms against treacherous rulers, Christians, Atheists, and Jews. On the other hand, IS has successfully waged Twitter war through the account @ShamiWitness. The account managed to spread religious narratives to attract the public. The Twitter account of @ShamiWitness has more than 17.700.000 followers and has sent thousands of pro-IS tweets, info about jihad, executions, information on IS fighters, and other IS agendas (Figure 1). Aside from @ShamiWitness, there are also several accounts of IS fighters on Twitter who have the same task: to construct people's thinking, broadcast hatred, wage wars, and make up the truth spread promises in the name of religion. Among the people on Twitter are@AmreekiWitness,@IronMuhajir,@Abu_lukman_al,@hijrah_jihad,@AbuMutassim03,@ AbuIzzadeen, and @TawheedNetwrk. 
A teenager manages @AmreekiWitness from Manassas (Virginia) named Ali Shukri Amin. Amin started@AmreekiWitness in 2014 and currently has more than 4.000 followers. Through his Twitter account, Amin spreads tweets to appeal to the public to wage war on those considered as IS's enemies with the promise of merit with Allah (Figure 2). Amin also plays a role in bridging community and IS groups ready to carry out warfare; he responsible for managing funding from members who wish to donate to IS using the 'dark wallet' to maintain donors' identity.

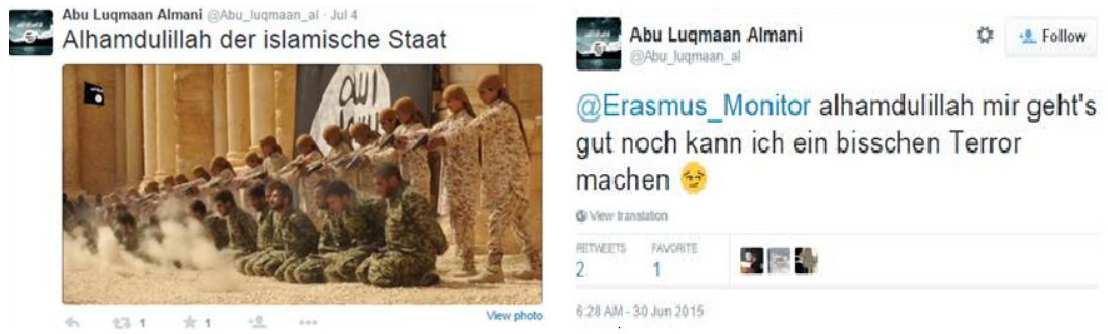

Figure 4.

Tweet of @Abu_lukman_al

Source: Counter Extremism Project (2015d)

Abu Adam al-Muhajir has the same task as Amin, and he spreads propaganda to urge the public to wage war by repeating the word 'jihad' in each of his posts. On 23 July 2013, al-Muhajir praised the concept of jihad and martyrdom and a better life reward for those who want to join the IS group (Figure 3). The tweet gives the message that IS fighters are willing to die to defend Islam's integrity and have the honor of being a martyr (a Muslim who died fighting in the way of Allah). Abu Lukman Almani often spreads digital war in the German language (Figure 4). In the tweet, Almani said, "Alhamdulillah Islamic country," and "Thank God I am fine, I can still create a little terror," with a photo of a prisoner who would be mass executed. The act was chosen to terrorize the public, provoking threats and showing the IS group's strength. The use of German is addressed to people who understand the language. Abu Mohammed is one of the IS members who are active on Twitter. Mohammed has expertise in constructing people's thinking through words to shape people's emotions (Figure 5). Abu Mohammed often said "forgiveness of sins" in every tweet. It was shown that he urged people to migrate, wage war for Allah, and fear not death based on the belief that if a jihadi fighter dies in a battle, all his sins during his life will be forgiven. This technique has proven that words could be more powerful weapons than a gun. They also maximize using symbols, pictures, and videos to gain sympathy and finally stir public emotion.

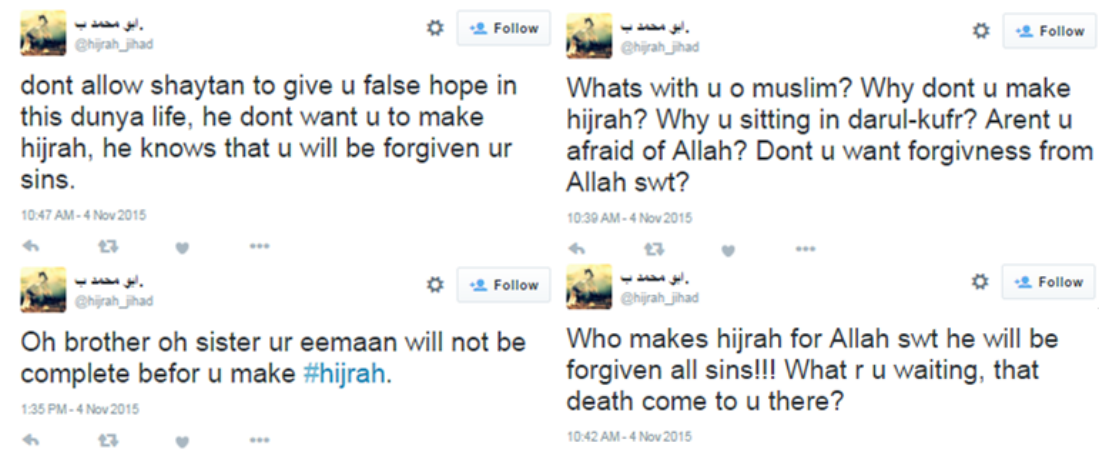

Figure 5.

Tweet of @hijrah_jihad

Source: Counter Extremism Project (2015e)

Abu Mutassim was a propagandist who blatantly expressed his antipathy for the United Kingdom. In some of his tweets, he said that Prime Minister David Cameron was a fanatical leader against Islam, and he was one of the obstacles to the establishment of an Islamic caliphate in the United Kingdom (Figure 6). Abu Mutassim also believes that the caliphate will stand in the United Kingdom as he perceived that the system would be beneficial for United Kingdom society. This post aims to frighten the enemy and attract Islamic State members' attention to fight to uphold the United Kingdom's caliphate. 
Unlike other propagandists, Abu Izzadeen is an active Twitter propagandist who was also the leader of radical groups in London. Some of his tweets incited Muslims in London to take up the fight against the United Kingdom and the United States and kill anyone who helped the two countries, as displayed in Figure 7. Not only calling for war; however Izzadeen also heavily participated in terrorist activities in the London attack on 22 March 2017, and the attack on the Regent's Park mosque in London. Abdurrohman's account is focused on spreading news regarding attacks carried out by IS members (Figure 8). It also distributes the information of killed members and their retribution from God. IS members also reckon of retaliation and avenge the death of to their members. Some tweets ridicule British Prime Ministers' policies and tweets claiming that the United Kingdom was a terror country and deserved IS members' attacks.

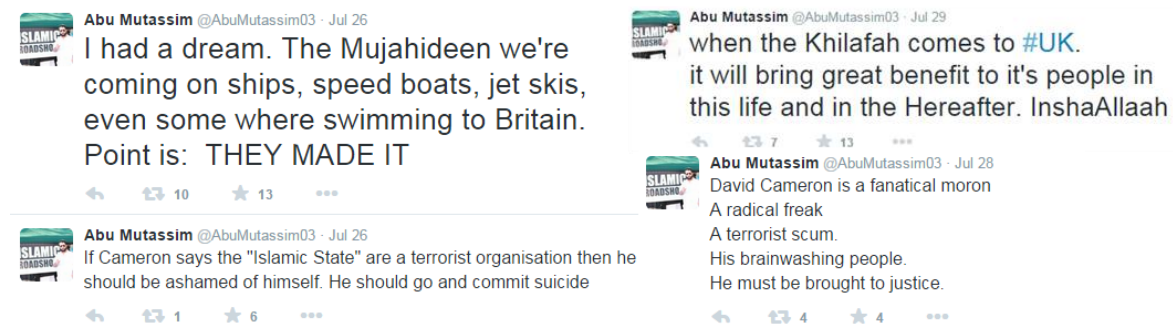

Figure 6.

Tweet of @AbuMutassim03

Source: Counter Extremism Project (2015f)
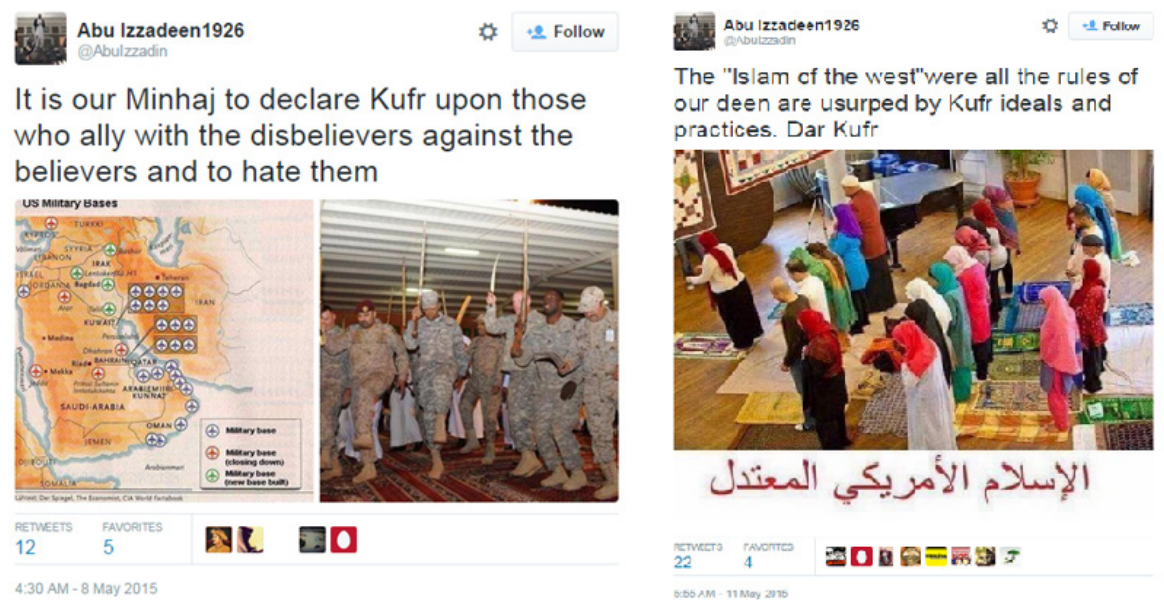

Figure 7.

Tweet of @Abulzzadeen

Sources: Counter Extremism Project (2015c)

\section{The United Kingdom Twitter propaganda}

The United Kingdom is a country with sophisticated development of science in the economy, technology, culture, and military (Gunarto 2003). Bridge (2010) explained that the United Kingdom is a country located in the European archipelago with a total land area of more than $243.600 \mathrm{~km}^{2}$, and the United Kingdom was formed on 1 January 1801, as a constitutional monarchy parliamentary democracy state. London is the United Kingdom's capital with several major countries, such as England, Wales, Scotland, and Northern Ireland. As a developed country, the United Kingdom has contributed to the world economy, especially in industry and technology.

Mod (2011) highlighted that technological and industrial advances support state development and bring positive economic growth changes. The United Kingdom's success in utilizing the internet has stimulated domestic trade growth and made it easier for the United Kingdom to cooperate and communicate with countries worldwide. Nevertheless, at the same time, technological advances change the way people live, causing many United Kingdom people to be technology-dependent in their daily lives. The dependency exposes United Kingdom society to the threat of cyber attacks. From 
some data, it is said that almost half of the United Kingdom population access the internet every day. Displays the statistical data for internet users in the United Kingdom shows in Figure 9, and it shows there has been an increase in internet users every year. This increase was motivated by the public's interest and dependence on the internet's facilities and conveniences regarding business, entertainment, games, organization, marketing, ease of communication, and unlimited access to information.

The use of the internet positively corresponds to the progress and use of social media. The United Kingdom citizens are the second most productive social media users in Europe after the Netherlands, the fourth biggest in the world after the United States, Brazil, and Japan. In 2012, the total United Kingdom population reached 63.7 million, and around 33 million of the population are active users of social media. Nearly $48 \%$ of the United Kingdom population has access to various forms of social media daily. The average population is around 18 to 24 years old. Facebook and Twitter are the two dominant social media preferred by the United Kingdom community from several existing social media.

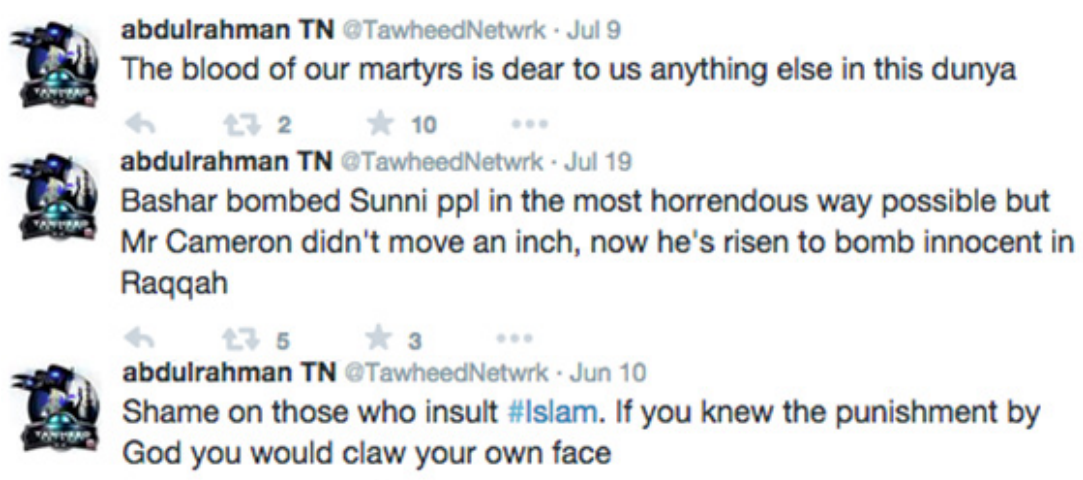

Figure 8.

Tweet of @TawheedNetwrk Sources: Counter Extremism Project (2015a)

Christopher (2015) stated that Facebook was dominated by female users, while men more favor Twitter users. Facebook is usually used to communicate with old friends, show status, and stylish events. Meanwhile, Twitter is used to speak directly to the public, whether in politics or about United Kingdom organizations and government. Twitter is often faster in responding to the news. Focusing on Twitter as a medium for bridging communities, organizations, and government, Figure 10 shows Twitter users' data in the United Kingdom from 2012 to 2018.

Figure 10 shows the number of Twitter users in the United Kingdom from 2012 to 2018 . There was an increase of users each year, starting from 8.6 million users in 2012 to 17.1 million users in 2018. As a country with the most internet or social media users, the United Kingdom is vulnerable to the risk of cyberattacks. Parliament of the United Kingdom (2019) revealed that the National Cyber Security Center(NSCS) had handled more than 1.100 cybersecurity incidents since October 2016, wherein cyber threats in the UK have accelerated every year and are gaining more technical complexity. As a response, the United Kingdom government has established several policies to improve domestic security, especially regarding the security of attacks that occur in online media. The United Kingdom has recently become a target country and attacks by extreme terrorists (IS) via Twitter. IS group have attacked the United Kingdom by spreading the word 'jihad' as a weapon to invite people to fight in cyberspace.

In the past few years, the United Kingdom has experienced extreme online attacks that influence people to radicalize. As a counter-attack measure, the United Kingdom formed an official Twitter account of @UKAgainstDaesh. Governments seek to counter IS attacks using the same platforms. Some of the tweets shared by the United Kingdom against IS on Twitter are shows in Figure 11. The tweet in Figure 11 warned the public about propaganda, radicalization, IS strategy, and IS goals. The United Kingdom explained further to the public about the situation in the field. They emphasized the word 'propaganda' by using a capital letter. It has portrayed how the United Kingdom has attempted to gain sympathy from the public. 


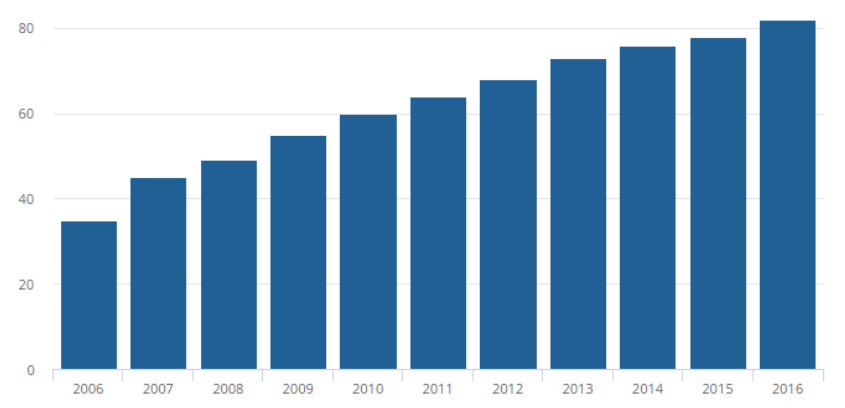

Figure 9.

The United Kingdom internet user statistics Source: Office for National Statistics (2016)

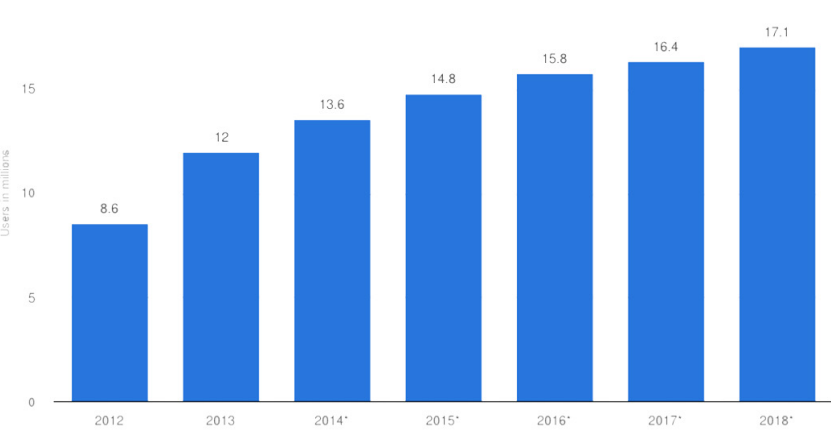

Figure 10.

Twitter users in the United Kingdom from 2012-2018

Source: Statista (2019)

The tweet shared on 8 March 2018, contained two key messages (Figure 12). First, the United Kingdom wanted to construct people's thinking about IS promises. Such as rewards, education, and a decent life for the people who join their movement. In this tweet, the United Kingdom implied that, if IS provides education, this is only a way to become a terrorist, while the United Kingdom provides education, especially to women, for stability in Iraq. In the second message, the United Kingdom wants to compare what IS has provided with what the United Kingdom has given to Iraq. Therefore, the United Kingdom expects people to grasp the idea the party deserves to be supported and which group should be abandoned and fought (resisted). Apart from the @UKAgainstDaesh account, the United Kingdom also collaborates with global coalitions, police, and internet company communities such as The Global Forum to Counter Terrorism (GIFCT) to fight IS attacks from various directions.

A tweet from@coalition explained IS's strategy through online media and their goal of spreading the message via Twitter. A tweet posted on 11 September 2017, "Do not help them by republishing it," uses black to emphasize the message conveyed (Figure 13). The United Kingdom tried to control the public from spreading IS messages indirectly through this tweet because circulating the messages helps the terrorist group. They added a picture of a sound image and a prohibition cross symbol to reinforce the message.

On 2 July, 2018, a Twitter account @TerrorismPolice reported that the United Kingdom government has collaborated with security partners to prioritize terror cases for domestic security by responding to all IS attacks and increasing their operational activities. The tweet indicated more than 600 investigations have been carried out by the police and have targeted around 3.000 people who were deemed a potential threat to the United Kingdom (Figure 14). Apart from fighting back through Twitter, the United Kingdom is also working with private technology communities such as GIFCT to block IS-related account, as shows in Figure 15. 
Blocking an account is an action aimed to enable an account to post updates (Figure 15). Hence, followers cannot access any information related to the account. GIFCT, a community of private technology associations (Facebook, YouTube, Twitter, and Microsoft), has completed the battle against IS on the digital platform. GIFCT was formed in 2017 to respond to David Cameron's statement that technology companies are also responsible for fighting terrorists, blocking or freezing accounts deemed to threaten state security. GIFCT applied a technique for accessing records using specific keywords known as 'hash' and 'fingerprints' that functioned as a security system on a computer network that protects against threats. These techniques are methods to identify videos, images, and text spread by terrorist groups via social media, including Twitter. GIFCT can quickly delete content related to terrorists or other radical acts even before the message is published to the community in cyberspace (Global Internet Forum to Counter Terrorism n.d.).

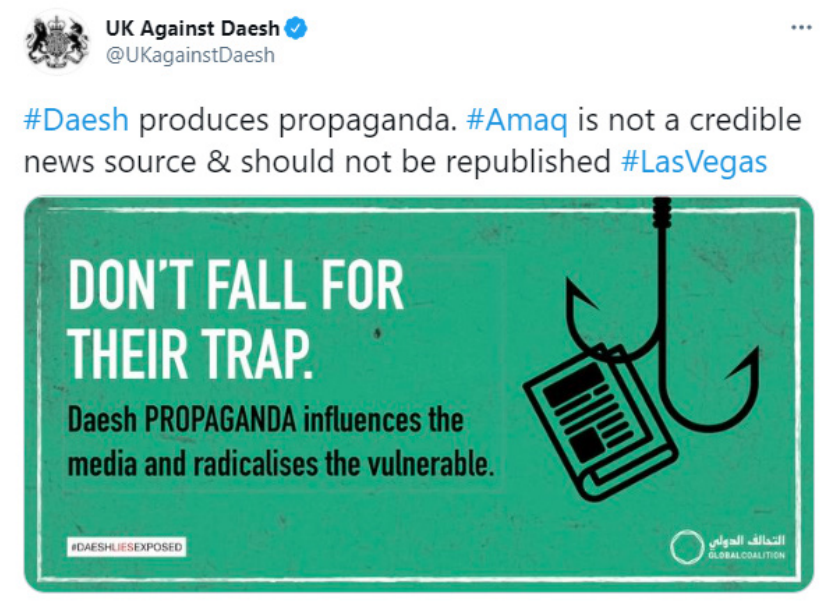

12:11 AM - Oct 3, 2017 - TweetDeck

Figure 11.

Twitter account of @UKAgainstDeash

Source: UK Againts Daesh (2017)

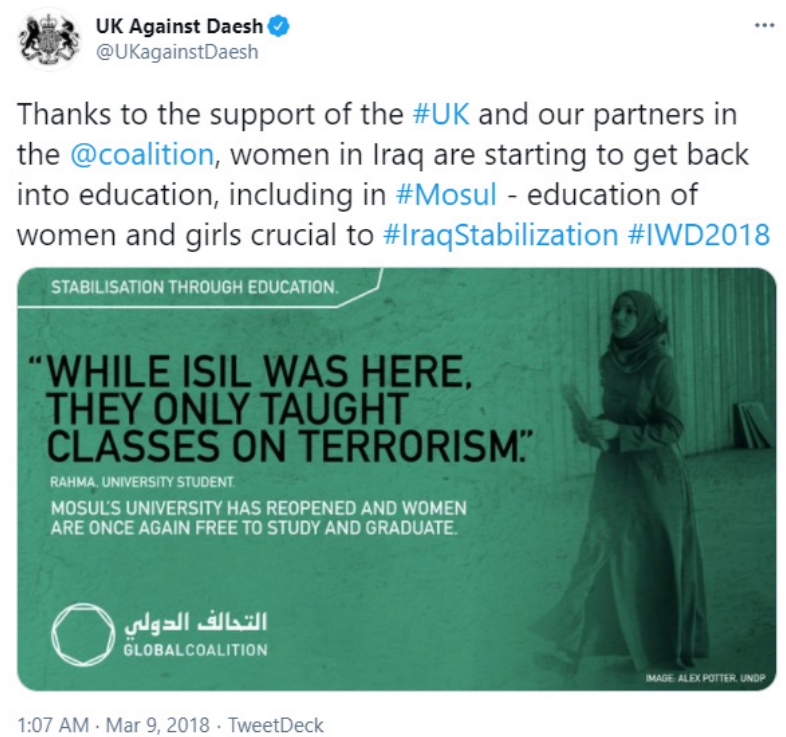

Figure 12.

Education in Iraq

Sources: UK Against Daesh (2018)

\section{Hard power pattern to counter the virtual attack of Islamic State from Twitter}

To successfully implement the soft power strategy, the government employed armless hard power attack, unlike the war in general. Arquilla \& Ronfeldt (2001) stated that the rigid power pattern has two objectives, 'oppose' as a form of resistance and 'support,' a proactive action aimed at peace (in 
this case, the 'support' method is not used). In opposing the occurring resistance, the state responds to the rejection of IS actions on social media, primarily via Twitter. For this measure, the United Kingdom collaborates with intelligence agencies and international organizations such as the United Nations. The purpose of this collaboration is to promote peace and has created a Counter Daesh Communication Call. In addition, the United Kingdom has also employed economic power to support countries experiencing IS attacks. This act was perceived as a form of resistance to IS undertakings to the United Kingdom.

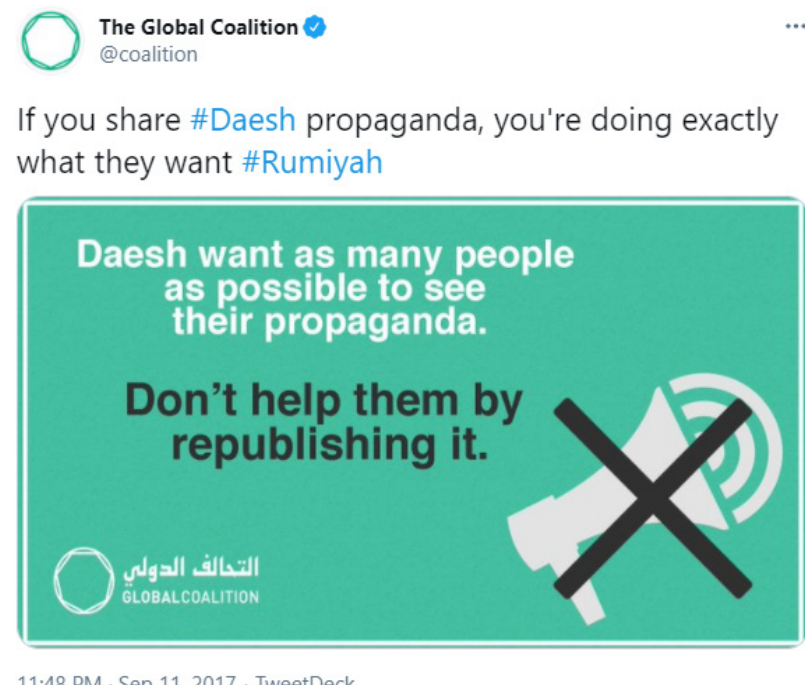

Figure 13.

Twitter account of @coalition that urges the public not to help IS propaganda

Source:The Global Coalition (2017)

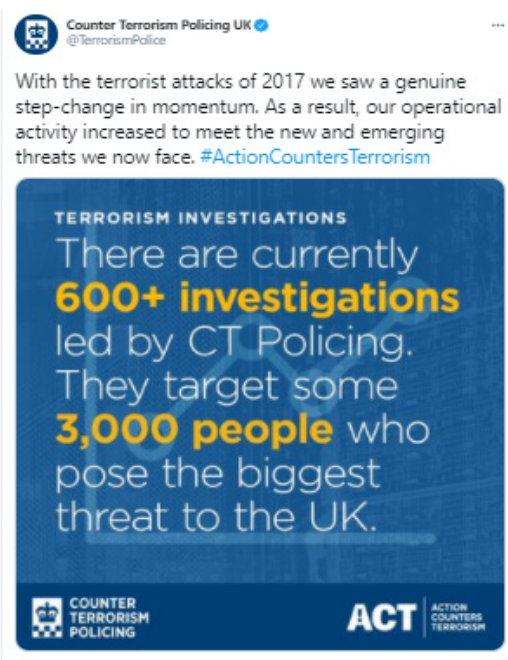

S.12 PM- Jul 2 2018- Twitter Mesia Studio

64 Retweets 1 Quote Tweet 70 izher

\section{Figure 14.}

The account of @TerrorismPolice about security

Source: Counter Terrorism Policing UK (2018)

The United Nations has a different strategy in combating IS attacks. They execute economic power by increasing the cost of prevention and fixing the problems that have been caused by IS from 2014 to 2017. This strategy aims to attract public sympathy as well as a game plan to defeat IS. Data from HC Debate (2017) explained that, in 2014, through the International Development Department, the United Kingdom government committed to providing 169.5 GBP million to help the Iraqi crisis. Most of the funds were used to facilitate clean water for the Iraqi people's needs, who experienced a clean water crisis. Apart from clean water, the funds were used to build houses and heating devices, such as blankets for thousands of heads of households, to survive in winter conditions. 
Data from the Government of the United Kingdom (n.d.) also noted that, since 2015, the United Kingdom government, with the United Nations, has contributed 103 GBP million to funds for conflict, security, and community stabilization, such as the repair of schools, hospitals, and infrastructure in Iraq. It recorded that 408.000 Iraqis have received food aid, two million people received toilet and shower facilities and 836.500 people have been given shelter, and more than 4.1 million people received health services. Meanwhile, in Syria, the United Kingdom supports a political process facilitated by the United Nations to resolve the conflict and protect Syrians' rights and has set aside 2.81 GBP billion. In addition, the British Prime Minister has provided more than 27 million meals, 14 million facilities for medical consultations, and provided all the necessities of 10.9 million goods for Syrians.
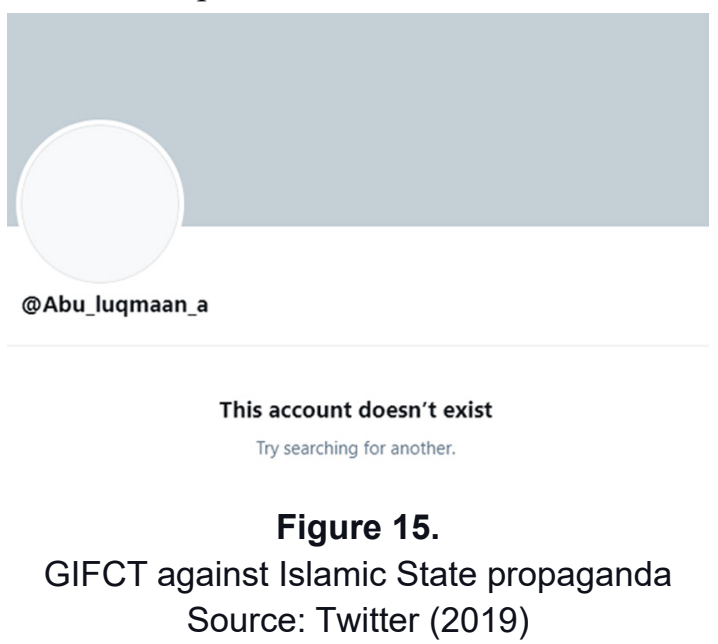

Additional data recorded that, in 2017, the United Kingdom again provided humanitarian assistance to victims of IS violence in Syria, especially in the Raqqa area. The United Kingdom government has provided 20.9 million food supplies in case of famine in the Raqqa region. The government also provided 700.000 formal education facilities for Raqqa children and 145.000 additional medical assistance at the hospital and repairing damaged health facilities. For psychological assistance for people who are traumatized by IS crimes, the government provides assistance to experts in the psychological field to heal them, and the government also provides access to clean water and 31.000 aid tools to fulfill their needs for daily activities (Patel 2017).

Information about aid provided by the United Kingdom government is often distributed through the government's official Twitter account @UKAgainstDaesh. The strategy aims to convey to the global community that the IS group is a group of violent people who violate human rights by committing murder, causing chaos, uprising, and destroying society's future. It shows in Figure 16, and the tweet implied that the United Kingdom is the capable state to fix the situation whenever the IS group causes chaos and damage. Syria is the recipient of more than 1.1 GBP billion in aid from the United Kingdom to handle the humanitarian crisis, provide access to clean water for 1.6 million people, provide nearly 20 billion food aid, and 2.5 billion facilities for health consultations Syrians.

Apart from international organizations, the United Kingdom also collaborates with intelligence agencies from major countries such as the United States, Canada, Australia, and New Zealand. This cooperation between state intelligence is known as five eyes. Dailey (2017) explained that five eyes were first formed by the United States and the United Kingdom intelligence during World War II. In 1948, Canada began to join the forces, followed by Australia and New Zealand in 1956, and their cooperation expanded to information exchanges about possible threats for members. The purpose of the cooperation is to reduce attacks, maintain domestic security and help members resolve securityrelated issues.

Bideaua (2019) reports that, by utilizing the power of technology, each intelligence agency could send information to other agencies via Signals intelligence (SIGNT). The information delivers through code that was understood only by intelligence group members. The mechanism relies on electronic 
systems intelligence, such as radar intelligence, computer system data, and weapon systems. Intelligence could gather information in two methods, first through Human intelligence (HUMINT), an act of collecting data from personal contacts whose intelligence source can interrogate, question, and answer and the media, and the second was Geospatial intelligence (GEOINT), where information about human activities obtains from satellites and maps.

The emergence of IS and their virtual attacks has become an essential concern for five eyes members as IS is considered a threat that disturbs national security. Regarding IS attacks, the United Kingdom has often received social media threats as a member of five eyes. Responding to such threats, other members support the United Kingdom to solve these problems. In the Manchester bomb attack in 2017, IS claimed responsibility for the attack, announcing it via tweets shared four hours before the incident. Other tweets threatened that the attack was only the start and there would be follow-up attacks (Figure 17).

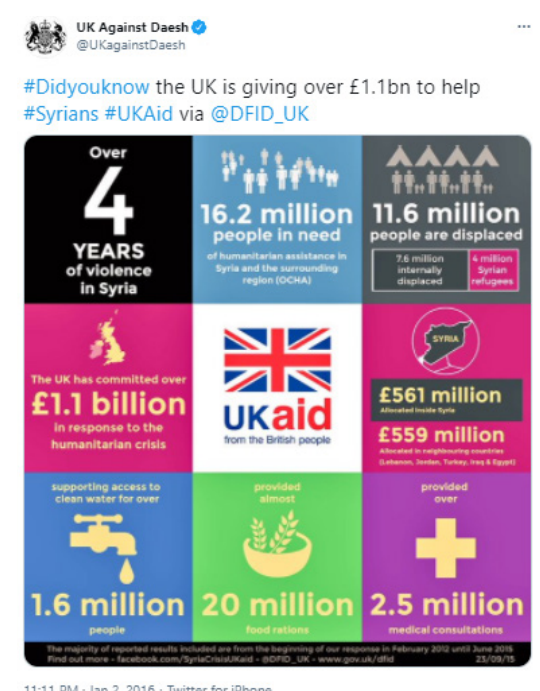

Figure 16.

Tweet @UKAgainstDaesh about the situation in Syria Source: UK Against Daesh (2016)

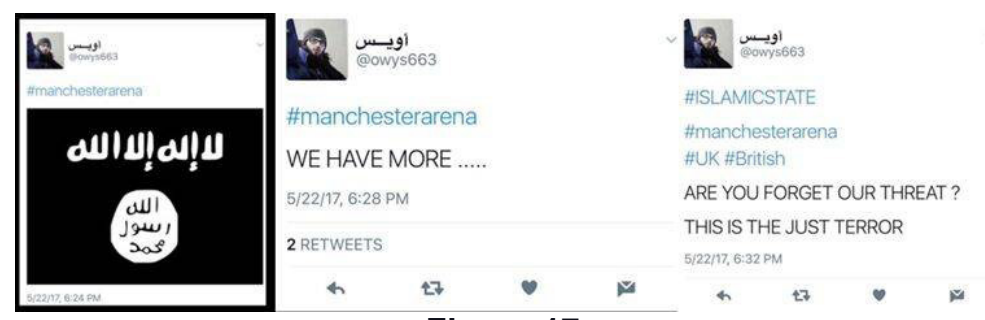

Figure 17.

Threatening tweet from the Islamic State (IS)

Source: The Indian Express (2017)

The three tweets posted on 22 May 2017 (Figure 17), at different times, yet information from these tweets was complementary. The first tweet was posted at $6: 24 \mathrm{pm}$, followed by a second at $6: 28 \mathrm{pm}$. The last tweet was at 6:32 $\mathrm{pm}$. The Manchester bombing occurred at 10:35 pm, four hours before the incident. Almasy et al. (2017) noted that, on 3 June 2017, three IS members launched another attack on London Bridge in central London, the three terrorists attacked people with knives. Seven people were killed, 48 people were injured, and the police shot the suspects. This attack occurred two weeks after the Manchester attack and the Westminster Bridge attack on 22 March 2017. The data recorded that, in 2017, the United Kingdom had experienced up to three consecutive attacks from the IS group.

In response to IS attacks, five Eyes intelligence conducted more than 500 live operations to enhance domestic security; thus, 20.000 people have been investigated as a threat. This phenomenon proves that IS attack techniques have changed (increasingly sophisticated), and people are being radicalized via computers and smartphones (Javid 2018). 


\section{Conclusion}

The advancement of communication and information technology has shifted the approach to warfare from conventional to psywar and evoking state response in various ways. The United Kingdom's policy to use Twitter to respond to Islamic State attacks can be categorized into two patterns: soft power and hard power. Regarding soft power, the United Kingdom created an official Twitter account in @UKAgainstDaesh to counter Islamic State attacks by emphasizing facts through videos, photos, and texts to convince audiences and gain sympathy, emotions, and support from the community. In addition, the United Kingdom also collaborates with Global Internet Forum to Counter Terrorism (GIFCT), private internet associations, such as Facebook, YouTube, Twitter, and Microsoft, to block terrorist-related accounts to prevent the public from accessing information related to terrorism.

The United Kingdom has also worked with the Global Coalition by forming@coalition and @ TerrorismPolice as a resistance strategy. In the sphere of hard power, the United Kingdom collaborates with the Police and Intelligence from big countries such as the United States, Canada, Australia, and New Zealand. The United Kingdom also collaborates with international organizations such as the United Nations. It exercises economic power by providing humanitarian assistance, education, health facilities, daily necessities, and others to countries with acts of violence, such as Iraq and Syria, to combat the Islamic State.

\section{References}

Alexander Y \& Alexander D (2015) The Islamic State, Combating the Caliphate Without Borders. London: Lexington Books.

Almasy S, Ellish R, Gallon N, \& George S (2017) London terror attack: Seven victims killed, three suspects shot dead by police. CNN, 4 June. [Accessed 1 February 2020]. https://edition.cnn. com/2017/06/03/europe/london-bridge-incident/index.html.

Arquilla J \& Ronfeldt D (2001) Networks and Netwars: The Future of Terror, Crime and Militancy. Santa Monica: RAND Corporation.

Atmowardoyo H (2018) Research methods in TEFL studies: Descriptive research, case study, error analysis, and R\&D. Journal of Language Teaching and Research 9 (1):197-204. https://doi. org/10.17507/j1tr.0901.25.

Back GI \& Thompson GR (2018) Military Communication. In: Encyclopedia Britannica. [Accessed 12 January 2019]. https://www.britannica.com/technology/military-communication.

Bideaua A (2019) The five eyes alliance is always watching. [Accessed 29 January 2020]. https:// www.cyberghostvpn.com/privacyhub/five-eyes/.

Boyle D \& Akbar J (2017) ISIS supporters celebrate terror attack on social media as Twitter confirms tweet 'predicting' Manchester attack was posted after the bombing. Mail Online, 23 May. [Accessed 8 May 2020] https://www.dailymail.co.uk/news/article-4532662/ISIS-fans-celeb rate-Manchester-terror-attack.html.

Bridge (2010) The United Kingdom of Great Britain and Northern Ireland. [Accesed 26 November 2019]. http://www.bridge-online.cz/wp-content/uploads/2016/09/01_uk_gov_places.pdf.

Channel 4 News (2014) Unmasked: The man behind top Islamic State Twitter account, 11 December. [Accessed 25 October 2019]. https://www.channel4.com/news/unmasked-the-man-behindtop-islamic-state-twitter-account-shami-witness-mehdi.

Christopher DP (2015) British Culture: An Introduction. London: Routledge.

Counter Extremism Project (2015a) Abdulrahman TN a.k.a@TawheedNetwrk. [Accessed 2 December 2019]. https://www.counterextremism.com/extremists/abdulrahman-tn-aka-tawh eednetwrk.

Counter Extremism Project (2015b) Abu Adam al-Muhajir. [Accessed 2 December 2019]. https:// www.counterextremism.com/extremists/abu-adam-al-muhajir.

Counter Extremism Project (2015c) Abu Izzadeen. [Accessed 2 December 2019]. https://www.coun terextremism.com/extremists/abu-izzadeen. 
Counter Extremism Project (2015d) Abu Luqmaan Almani a.k.a. @Abu_luqmaan_al. [Accessed 2 December 2019]. https://www.counterextremism.com/extremists/abu-luqmaan-almani-akaabuluqmaanal.

Counter Extremism Project (2015e) Abu Mohammed B. a.k.a. @hijrah_jihad. [Accessed 2 December 2019] https://www.counterextremism.com/extremists/abu-mohammed-b-aka-hijrahjihad.

Counter Extremism Project (2015f) Abu Mutassim a.k.a. @AbuMutassim03. [Accessed 2 December 2019] https://www.counterextremism.com/extremists/abu-mutassim-aka-abumutassim03.

Counter Terrorism Policing UK (2018) 2 July. [Accessed 5 December 2019]. https://twitter.com/ TerrorismPolice/status/1013709405685211136.

Dailey J (2017) The intelligence club: A comparative look at five eyes. Journal of Political Sciences \& Public Affairs 5 (2):1-8. https://doi.org/10.4172/2332-0761.1000261.

Dickson KD (2004) War in (another) new context: Postmodernism. Journal of Conflict Studies 24 (2):78-91.

Global Internet Forum to Counter Terrorism (n.d.) About. [Accessed 25 November 2019] https:// www.gifct.org/about/.

Government of the United Kingdom (n.d.) UK action to combat Daesh. [Accessed 11 October 2019]. https://www.gov.uk/government/topical-events/daesh/about.

Greenberg J (2015) Does the Islamic State post 90,000 social media message each day? Politifact, 19 February. [Accessed 25 November 2019]. https://www.politifact.com/punditfact/statements /2015/feb/19/hillary-mannleverett/cnn-expert-islamic-state-posts-90000-social-media-/.

Gunarto H (2003) Riset dalam bidang teknologi dan ilmu pengetahuan untuk peningkatan taraf ekonomi suatu negara. Buletin Informatika 4 (1):14-19.

Hall J (2014) 'How is democracy treating you guys?' ISIS militants take to social media to encourage Ferguson protesters to embrace Islamic extremism. Mail Online, 19 August. https://www. dailymail.co.uk/news/article-2728624/How-democracy-treating-guys-ISIS-militants-socialmedia-encourage-Ferguson-protesters-embrace-Islamic-extremism.html.

Harrison S (2018) Evolving tech, evolving terror: New perspectives in foreign policy. Centre for Strategic \& International Studies 15 (2018):28-33.

HC Debate (2017) Volume 623, Column 444, 15 January. [Accessed 25 October 2019]. https:// hansard.parliament.uk/Commons/2017-03-15/debates/1E60412F-3048-4792-899CB463C1A2A635/Counter-DaeshUpdate.

Javid S (2018) Home secretary announces new counter-terrorism strategy. [online]. Home Office, 4 June. [Accessed 2 February 2020]. https://www.gov.uk/government/speeches/home-secreta ry-announces-new-counter-terrorism-strategy

Metz S (2007) Rethinking Insurgency. United Kingdom: Juniper Grove.

Mod U (2011) The UK Cyber Security Strategy Protecting and Promoting the UK in a Digital World. London: Cabinet Office.

McLean AT (1993) WWI: Technology and the weapons of war. In: NCPedia. [Accessed 8 May 2020] https://www.ncpedia.org/wwi-technology-and-weapons-war.

Muhammad R (2015) ISIS Mengungkap Fakta Terorisme Berlebel Islam. Jakarta: Noura Books.

Office for National Statistics (2016) Internet access - households and individuals, Great Britain: 2016. [Accesed 2 February 2020]. https://www.ons.gov.uk/peoplepopulationandcommunity/ householdcharacteristics/homeinternetandsocialmediausage/bulletins/internetaccesshouse holdsandindividuals/2016.

Parliament of the United Kingdom (2019) Delivering the national cyber security strategy. [Accessed 15 March 2020]. https://publications.parliament.uk/pa/cm201719/cmselect/cmpubacc/1745/ 174506.htm\#_idTextAnchor005.

Patel P (2017) As ISIS is wiped out in Raqqa, British foreign aid can help rebuild victims' lives. The Sun, 22 October. [Accessed 2 February 2020]._https://www.thesun.co.uk/news/4740244/isisraqqa-foreign-aid-priti-patel/\#comments. 
Perraudin F (2015) UK launches Twitter account to combat Islamic State propaganda. The Guardian, 28 August. [Accessed 25 October 2019]. https://www.theguardian.com/world/2015/aug/28/ uk-foreign-office-twitter-account-combat-islamic-state-propaganda-isis.

RAND (2019) The Islamic State (Terrorist Organization). [Accessed 20 August 2019] https://www. rand.org/topics/the-islamic-state-terrorist-organization.html.

Statista (2019) Number of Twitter users in the United Kingdom (UK) from 2012 to 2018 (in million users). [Accessed 25 October 2019]. https://www.statista.com/statistics/271350/twitterusers-in-the-united-kingdom-uk/.

Stuart H (2014) British Jihadists: Preventing Travel Abroad and Stopping Attacks at Home. London: The Henry Jackson Society.

The Global Coalition (2017) 11 September. [Accessed 25 October 2019]. https://twitter.com/coali tion/status/907284604058402817.

The Indian Express (2017) Manchester Arena blast: This unverified Twitter account 'predicted' the attack 4 hours before it happened, 23 May. [Accessed 1 February 2020]. https://indianexpress. $\mathrm{com} /$ article/trending/this-is-serious/manchester-arena-blast-this-unverified-twitter-accountpredicted-the-attack-4-hours-before-it-happened-4669424/.

Tomé L (2015) The "Islamic State": Trajectory and reach a year after its self-proclamation as a "Caliphate." Journal of International Relation 6 (1):116-139.

Twitter(2019)@Abu_luqmaan_a’s Profile. [Accessed 5 December 2019]. https://twitter.com/Abu_ luqmaan_al.

UK Against Daesh (2016) 2 January. [Accessed 2 February 2020] https://twitter.com/ukagainstdaesh/ status/683304504788430848.

UK Against Daesh (2017) 3 October. [Accessed 11 October 2019]. https://twitter.com/UKagainst Daesh/status/914900536805220352.

UK Against Daesh (2018) 9 March. [Accessed 11 October 2019]. https://twitter.com/UKagainstDa esh/status/971809523739611136. 